УДК: 7.036(4), 069.02:7

ББК: 79.17

A43

DOI: $10.18688 / \mathrm{aa} 200-5-66$

V. Benedettino

\title{
Werner Haftmann as the Director of the Neue Nationalgalerie in Berlin (1967-1974): Survey of the Curatorial Concept in the West German National Modern Art Gallery during the Cold War
}

The following paper will present preliminary results related to key aspects of Werner Haftmann's curatorial activity as the director of the Neue Nationalgalerie in Berlin from 1967 until 1974. The archival research was undertaken in several public archives in Germany and Italy in the frame of my Ph. D. at Universität Heidelberg and École du Louvre in Paris ${ }^{1}$. Firstly, Haftmann's biography will be briefly outlined in order to contextualize his career as an art historian in the first half of the $20^{\text {th }}$ century in Germany, Italy, and after World War II in West Germany. Afterwards, the circumstances of his appointment as the director of the Neue Nationalgalerie, built by the renowned architect Mies van der Rohe in West Berlin from 1965 until 1968, will be discussed. Finally, Haftmann's curatorial concept concerning temporary exhibitions and artworks purchase policy, in addition to his statement about the mission of a national modern art museum will be highlighted.

The professional career of Werner Gustav Haftmann (1912-1999) must be analysed in the light of the turbulent political and historical events that occurred in Germany during the $20^{\text {th }}$ century. The art historian started a successful career in the 1930s during the repressive Nazi regime and consolidated it after World War II, in the time of West Germany's reconstruction. As a young scholar in Berlin and later on in Göttingen, he devoted himself to the study of the Florentine Renaissance. In doing so, he carefully positioned himself far away from the dangerous battleground over modern art, which was considered degenerate by Nazi ideology. In the post-war time, instead, Haftmann played a leading role in the defence of the once-banned avant-garde art movements and artists through his books and curatorial work in museums and galleries in the Federal Republic of Germany and abroad. Moved by the need to rehabilitate modern art after the National Socialism, Haftmann acquired popularity and recognition as an art historian during a time characterized by the ideological struggle regarding

Ph. D. in Art History at Universität Heidelberg and École du Louvre, Paris titled: "Werner Haftmann Leiter der Neuen Nationalgalerie in Berlin. Wechselausstellungen und Ankaufspolitik (1967-1974)" under the supervision of Prof. Henry Keazor and Prof. Cécilia Hurley-Griener. The Ph. D. is funded by a BadenWürttemberg Scholarship at Zentralinstitut für Kunstgeschichte in Munich (2017-2019) and a "Paris X Rome Fellowship" at Deutsches Forum für Kunstgeschichte in Paris, Max Weber Stiftung, and Bibliotheca Hertziana, Max Planck Gesellschaft, Rome (2019-2020). 
art and culture between the opposed political and socioeconomic systems ruling over the country divided by the Iron Curtain.

Haftmann (Fig. 1) was born on April 28, 1912, in the West Prussian city of Glowno in the former German province of Posen, present-day Poland ${ }^{2}$. Only a few facts are known about his family and childhood, and the available sources about this subject include his resumes ${ }^{3}$. In a resume dated 1958, for example, Haftmann stated that, in 1919, his family was forced to move to Upper Silesia due to the national Polish uprising and that as a child, he went to school in different towns in Upper Silesia and Silesia before moving to Magdeburg, where he obtained his high school diploma in 1932. In the same year, Haftmann was awarded a scholarship by the Studi-

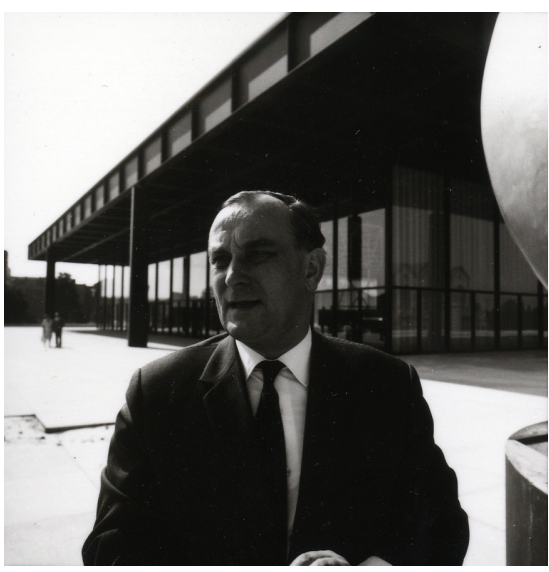

Fig. 1. Werner Haftmann in front of the Neue Nationalgalerie. Berlin, 1968. (C) SMB, Zentralarchiv/Reinhard Friedrich enstiftung des deutschen Volkes and enrolled in the Faculty of Art History and Archaeology at the Friedrich-Wilhelm University in Berlin ${ }^{4}$. In the capital, Haftmann came into contact with different sculptors and painters pertaining to the Künstlergemeinschaft Klosterstraße, a community formed by artists with heterogeneous artistic styles and political backgrounds, such as sculptors Ludwig Kasper (1893-1945) and Hermann Blumenthal (1905-1942), painters Werner Gilles (1894-1961) and Hermann Teuber $(1894-1985)^{5}$. In 1934 and 1935, the young art historian wrote his first articles about German modern art published in the magazine Kunst der Nation $[10 ; 11 ; 12 ; 13 ; 14]$. The document kept at the Humboldt University Archives in Berlin provides evidence that Haftmann joined the Sturmabteilung (SA) in $1933^{6}$. Furthermore, his NSDAP membership card is stored at the Bundesarchiv in Berlin ${ }^{7}$. After World War II, he wrote in his denazification dossier that he became a member of the so-called "Brownshirts" to obtain a student visa for a study trip to Italy in 1934. In 1935, Haftmann left Berlin and moved to Göttingen with the aim of conclud-

Akte Z/B II 1376 Akte 24 Ka 097, Universitätsarchiv der Humboldt-Universität, Berlin.

Unfortunately, Haftmann's widow didn't allow me to consult Werner Haftmann's private documents stored in public archives in Germany, which require a special permission from his relatives. Documents related to Haftmann's family accessible in public archives include: the register of death of Haftmann's father, Karl Ernst Gustav Haftmann (Sterbeeintrag Magdeburg-Altstadt 1934, Nr. 1690), and a personal file about Haftmann's mother, Hedwig Haftmann (PA 10395, Hedwig Haftmann), both stored in the Stadtarchiv Landeshauptstadt Magdeburg, as well as Haftmann's baptism file contained in the protestant church register office of Hannover available on the website Ancestry.com (Rheinland, Deutschland, evangelische Kirchenbücher, 1533-1950), available at: https://www.ancestry.de/search/?name=Werner_Haftmann (accessed 31 January 2019).

$4 \quad$ Resume written by Werner Haftmann dated 22.02.1958, Registratur III.1.18, Lehrstühle Berufungen 1949-1958, III/11 Verhandlungen Generalsekretär-Dr. Schwend, Dr. Haftmann-Prof. Dr. Schmidt 1958, Archiv der Akademie der bildenden Künste München.

I here thank Prof. Angela Lammert to letting me read the unpublished letter that Werner Haftmann wrote to her, dated 01.02.1994, N. 1560, Historisches Archiv Akademie der Künste, Berlin.

Akte Z/B II 1376 Akte 24 Ka 097, Universitätsarchiv der Humboldt-Universität, Berlin.

BArch, R 9361-IX KARTEI/13020147, Bundesarchiv, Berlin. 
ing his studies under professor Georg Vitzthum. According to Haftmann, he moved from Berlin immediately after returning from his study trip to Italy in order to avoid inquiries and once in Göttingen he had no further contact with the SA organization ${ }^{8}$. He earned his $\mathrm{PhD}$ in 1936 with a dissertation on the afterlife of Antiquity during the Middle Ages and until the early Renaissance in Italy [16]. As a student, Haftmann was already considered a very talented art historian. This is proven by the Vienna University professor Julius von Schlosser's report about his doctoral thesis?.

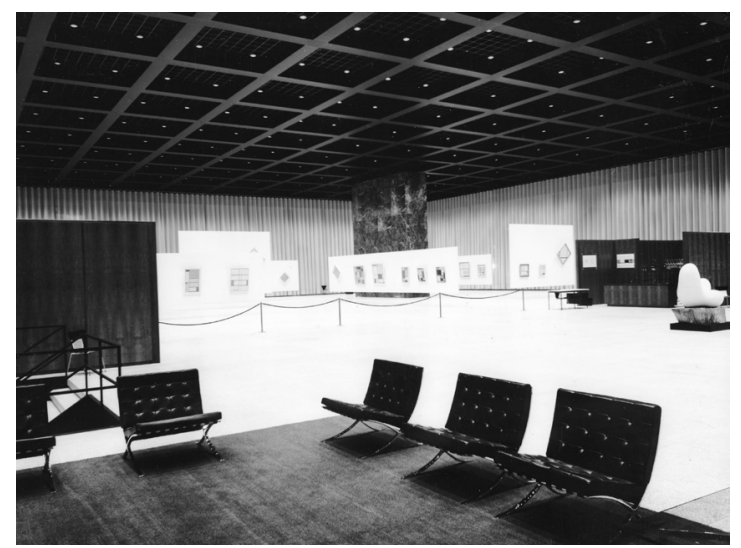

Fig. 2. Piet Mondrian Exhibition, Neue Nationalgalerie. Berlin, 1968. (C) SMB, Zentralarchiv/Reinhard Friedrich

In the same year of his graduation, he was appointed as the first assistant of Friedrich Kriegbaum (1901-1943), the director of the Germanic Art Historical Institute in Florence, where he continued his studies of the Renaissance $^{10}$. In 1939, he was about to become an assistant to Hans Sedlmayr (1896-1984), a professor of Art History at the Vienna University and a Nazi sympathizer. In his recommendation letter in support of Haftmann's application, Kriegbaum praised Haftmann as an aligned National Socialist as well as a member of the $\mathrm{SA}^{11}$. In 1940, Haftmann was fired from his post at the Florentine institute. According to Haftmann, his dismissal was due to his publicly expressed disagreement with the National Socialist politics during a meeting of German intellectuals ${ }^{12}$ [35, p. 87]. After having served as a liaison officer and a translator at the German connection delegation with the Italian Armistice Commission with France in Turin ${ }^{13}$, Haftmann stated that he fought in Italy, France, and North Africa. In 1945, he was imprisoned at the Rimini camp in Northern Italy returning to West Germany, in the town of Kalkar, one year later as a refugee ${ }^{14}$.

From 1946 on, the art historian began dedicating his studies to $20^{\text {th }}$-century German and European avant-garde artists and published numerous essays [21] and books that became bestsellers, like, for example, the volume Paul Klee. Wege bildnerischen Denkens edited

\footnotetext{
$8 \quad$ NW 1012, Nr. 10378, Landesarchiv NRW, Abteilung Rheinland, Duisburg.

9 Promotionsakten No. 763, Letter from Julius von Schlosser dated Wien, 26.V.38, SUB Niedersächsische Staats- und Universitätsbibliothek Göttingen.

10 SMB-ZA, III/VKI, 023.

11 Nachfolge Novotny, Archiv des Instituts für Kunstgeschichte der Universität Wien.

12 Haftmann refers to this fact in his denazification dossier: NW 1012, Nr. 10378, Landesarchiv NRW, Abteilung Rheinland, Duisburg.

13 BArch RW 59/2139, Kartei Sonderführer, Karten 1-2, Bundesarchiv, Abteilung Militärarchiv, Freiburg im Breisgau.

$14 \quad$ NW 1012, Nr. 10378, Landesarchiv NRW, Abteilung Rheinland, Duisburg; I here thank Ms. Anna Gamerschlag (Stadtarchiv Kalkar) for indicating me that a card of the residents' registration office states that Haftmann registered in Kalkar on January 25, 1947. On June 19, 1950, Haftmann registered permanently in Gauting, close to Munich.
} 
in 1950 [15]. Moreover, he committed himself to supporting the career of German artists born around the first decade of the $20^{\text {th }}$ century who shared a common path: they had been acclaimed artists on the art scene before the Nazis took power in 1933 and banned them [22]. Artists like Ernst Wilhelm Nay (1902-1968) and Fritz Winter (1905-1976), to whom Haftmann dedicated several books ${ }^{15}$, made successful comebacks during the post-war period because they were strongly supported by art the historians like Haftmann who named them the

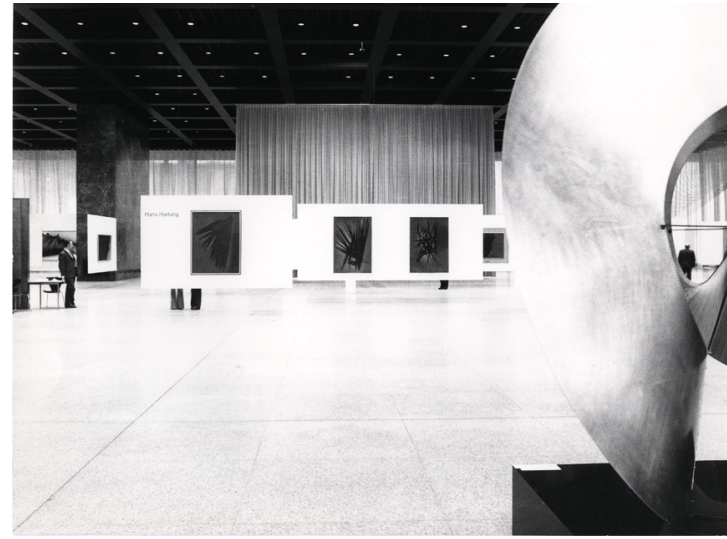

Fig. 3. Hans Hartung Exhibition, Neue Nationalgalerie. Berlin, 1975. (C) SMB, Zentralarchiv/Reinhard Friedrich heirs of the great masters of the avantgarde movements [34, pp. 4-5]. The first Documenta titled The Art of the $20^{\text {th }}$ Century. International Exhibition at Museum Fridericianum, which was curated by Haftmann and took place in Kassel in 1955 [2], represented the tangible display of this intention to reconnect the West German post-war contemporary art scene with the glorious art movements that emerged at the beginning of the $20^{\text {th }}$ century in Germany such as The Blue Rider and the Bauhaus [34, pp. 4-5].

In 1949, Haftmann established himself in Murnau, a town located near Munich ${ }^{16}$. In Munich, he collaborated with the Bavarian radio on programs about the history of art and literature ${ }^{17}$, and with the American art historians based at the Central Collecting Point, participating in cultural events curated by Stefan Munsing, responsible for the cultural Re-Education program in Bavaria ${ }^{18}$ [30, pp. 198-217]. Haftmann explicitly supported the abstract and informal art movements, proclaiming in his inaugural speech of the second Documenta (in 1959) titled Painting after 1945: Paintings, Sculptures, Graphic Arts that art has become abstract and that abstractionism was the new universal art language in the free and democratic Occidental world [25, pp. 41-58]. Unlike the Socialist Realism, which was directly supported by the communist party of the German Democratic Republic, Haftmann considered abstract art as the only artistic movement that could express artistic freedom and consequently avoid political manipulation [34, p. 7]. Whether or not Haftmann's engagement with non-figurative art movements had political roots supported by the American cultural policy has not been proven yet.

15 See the publications' list on Ernst Wilhelm Nay and Fritz Winter on Werner Haftmann's website. Available at: http://werner-haftmann.de/literatur/monografien/\#nay; http://werner-haftmann.de/literatur/ monografien/\#winter (accessed 31 January 2019).

16 NW 1012, Nr. 10378, Landesarchiv NRW, Abteilung Rheinland, Duisburg.

17 SN/90.1; SN/90.2; SN/91.2; SN/96.2; SN 95.1; SN 94.2; SN/97.2; SN/118.1; SN 119.2; SN/114.1; SN/125.2; SN/126.2; SN/112.1; SN/105.2; SN/100.2, BR, Historisches Archiv, Munich.

18 Haftmann participated in the jury for the Blevins-Davis-Preis for young German artists in 1949 and gave the inaugural speech during the opening of the exhibition Kunstschaffen in Deutschland in 1949. 
Haftmann's publications, curatorial activities and his teaching post at the Hochschule für Bildende Künste in Hamburg [38, p. 246] turned him into a renowned and appreciated art historian in West Germany. As we mentioned above, he was appointed by Arnold Bode as the curator of the first three Documenta exhibitions in Kassel in 1955, 1959 and 1964 [2; 3; 7]. Furthermore, he was invited by Alfred H. Barr Jr. to curate the exhibition German Art of the $20^{\text {th }}$ Century in 1957 at the Museum of Modern Art in New York [4]. Also, in 1958, he was selected by the general director of the Bavarian National Art Galleries, Kurt Martin, to become a member of the modern artworks acquisition com-

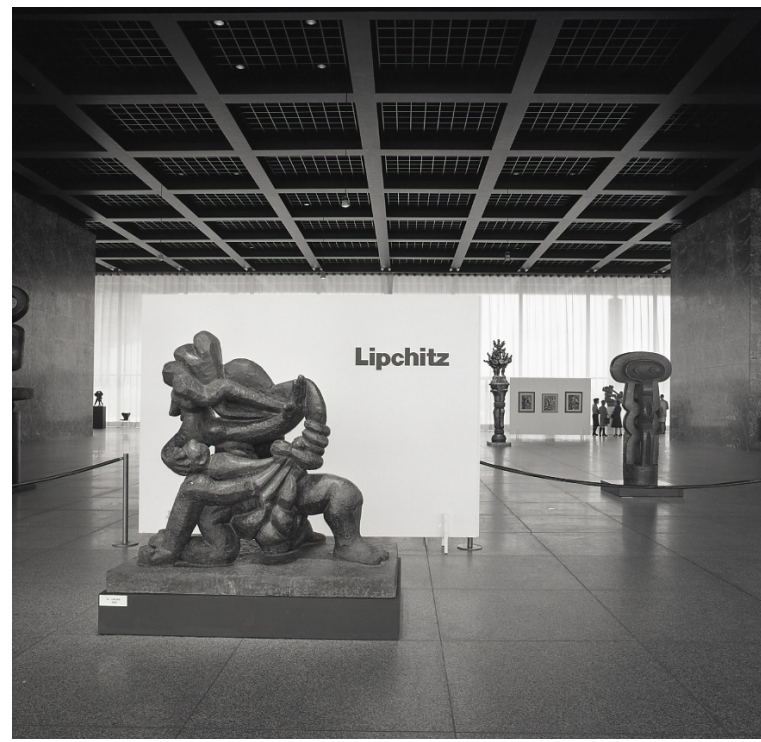

Fig. 4. Jacques Lipchitz Exhibition. Neue Nationalgalerie. Berlin, 1970. (C) SMB, Zentralarchiv/Reinhard Friedrich mittee at the Neue Pinakothek ${ }^{19}$.

In 1961, the construction senator of the Land of Berlin, Rolf Schwedler (1914-1981) and the senate building director Werner Düttman (1921-1983) commissioned Ludwig Mies van der Rohe (1886-1968) the building of a new museum in West Berlin [5, p. 3] in an area called Kulturforum [27]. After the division of the city, all national museums on the Museum Island, including the Nationalgalerie, were located in East Berlin [28, p. 11]. The collections to be displayed in the Neue Nationalgalerie consisted of the artworks of the Nationalgalerie that survived the Nazi campaigns against "degenerate art" together with the artworks of the Galerie des 20 Jahrhunderts that was established in 1945 and directed since then by Adolf Jannasch (1898-1984) [20, p. 35]. Werner Haftmann was appointed the director of the Neue Nationalgalerie in 1966 by Stephan Waetzoldt (1920-2008), the general director of the national museums in Berlin, and started his job officially in 1967 [6, p. 7].

The analysis of contemporary press articles demonstrates that Haftmann's appointment as the head of the Neue Nationalgalerie in Berlin was welcomed and criticized at the same time. Haftmann was a respected art historian and had many connections in the German and international art world, as well as in the art market. Nevertheless, his ideological theories stating the triumph of abstract art as the art movement of the future were considered outdated. As art critic and writer, Heinz Ohff wrote in the article Fifteen years too late. Werner Haftmann as the director of the Nationalgalerie? published on May 6, 1966, in Der Tagesspiegel Berlin, the fact that new art movements such as Pop Art, Nouveau réalisme, Conceptual Art, and Performance

19 Letter 13/1 Nr. 3624 dated 16 July 1958 from Kurt Martin to the Bayerisches Ministerium für Unterricht und Kultus, Reg. 422 13/1 1947-1966 Ankaufskommission, Archiv der Neuen Pinakothek, Munich. 
Art had arisen during the 1960s, demonstrated the overcoming of Haftmann's standpoint ${ }^{20}$.

The curatorial concept applied by Haftmann to the Neue Nationalgalerie shows several similarities with that developed for his Documenta shows. His aim was to create a "world gallery," a model collection with best examples of modern works of $\operatorname{art}^{21}$. In shaping the new collection, he focused on the idea that "art is what great artists do" highlighting the individual performance of famous artists instead of the contribution of art movements and therefore acquiring masterpieces by artists already recognized by art critics. His temporary exhibitions program was based on the same principle (Fig. 2). Starting with the opening exhibition of Piet Mondrian in 1968 [17], Haftmann dedicated the solo shows to artists such as Ernst Wilhelm Nay (1969) [18] and Jacques Lipchitz (1970) [19] ending his mandate with the retrospective of Hans Hartung (Fig. 3), which took place a year after his leave from the museum (1975) [32] $]^{22}$.

In the article Nationalgalerie 1967-1974. A retrospect published by the Stiftung Preußischer Kulturbesitz in the yearbook of 1976, Haftmann declared that the task of directing a museum with such a long history and tradition like the Nationalgalerie meant for him to transcend his personal artistic taste as an art historian [20, p. 33]. Despite this, it is interesting to remark that his book Painting in the $20^{\text {th }}$ Century published in 1954 [23] and followed the next year by an illustrated tome [24] played a significant role in the museum's acquisitions and exhibitions program. The volume is an encyclopaedia of modern art that is nowadays recognized as having been used as a guideline to display the Documenta exhibitions curated by Haftmann in Kassel [34, p. 5]. Scholars like Walter Grasskamp, for instance, consider these shows as an expression of a partial Western European aesthetic viewpoint of modern art before and after World War II [9, pp. 97-105].

In his commemorative speech for the centenary of the Hamburger Kunsthalle in 1969, Haftmann expressed himself unequivocally about his museological concept causing a passionate debate among modern art museums directors, which took place in the following months on the pages of Die Zeit newspaper. Wieland Schmied, the Kestner Gesellschaft's director in Hannover, who declared to be particularly concerned by Haftmann's conservative positions in regard to contemporary art, replied with the article The Mission Is the Present Age: Thoughts about an Expanded Museum published on September 12, 1969'3. In his speech Haftmann, who considered the museum as a moral institution, defended indeed the traditional conception of the museum against those who claimed for its democratisation. Moreover, he openly positioned himself against contemporary art movements that questioned the materiality of artworks in favour of conceptual ideas or performances. Finally, he rejected the possibility that modern art museums could turn into project spaces acting as experimental fields for young artists. In his view, the museum's task consisted in keeping alive the artistic movements

\footnotetext{
20 Presse-AdK-W 062, Presse-Archiv, Historisches Archiv Akademie der Künste, Berlin.

$21 \quad$ M. S. Der Chef ist da! Der Abend. 25.02.1967. Presse-Archiv, Historisches Archiv Akademie der Künste, Berlin.

22 Other temporary solo shows in the museum's hall were dedicated to: Afro Basaldella (1969); Roberto Matta (1970); Mark Rothko (1971); Wilhelm Lehmbruck (1973); Antoni Tàpies (1974).

${ }_{23}$ Schmied W. Der Auftrag lautet Gegenwart. Gedanken zu einem erweiterten Museum. Die Zeit. 12 September 1969. Available at: https://www.zeit.de/1969/37/der-auftrag-lautet-gegenwart (accessed 31 January 2019).
} 
of the past and therefore protecting the mother of all muses, the museum's memory muse Mnemosyne [26, pp. 69-79].

The monumental spaces created by Mies van der Rohe to display the collections at the Neue Nationalgalerie [37] deeply impacted Haftmann's acquisition policy as well as his temporary exhibitions program [20, p. 36]. For the challenging open space gallery on the ground floor designed for temporary exhibitions, the architect conceived the system of hanging walls that could be mounted and dismantled as needed [31, p. 10]. This museographical display was strongly influenced by the American art historian, James Johnson Sweeney (1900-1986). As the director of the Museum of Fine Arts Houston, where Mies van der Rohe built a new wing called Cullinan Hall in 1958 [8], Sweeney was the first director facing the challenge of displaying artworks in an open space gallery without walls designed by the German architect [36, pp. 38-43]. The Neue Nationalgalerie disruptive museum architecture, particularly suitable to exhibit big artworks, created considerable problems in terms of displaying a collection that was predominantly constituted of smalland medium-size works of art [20, pp. 33-53].

Haftmann's standpoint concerning his role as the museum director manifests contradictions: on the one hand, the art historian aimed at inscribing his work in an objective frame reconnecting his activities to the accomplishments of foregoing Nationalgalerie's directors like Hugo von Tschudi (1851-1911) and Ludwig Justi (1876-1957), who at the beginning of the $20^{\text {th }}$ century contributed to create a world-famous modern art collection displayed at Kronprinzenpalais [29, p. 68]. On the other hand, at the Neue Nationalgalerie between 1967 and 1974, Haftmann exhibited the artists and art movements that he strongly supported; for instance, the abstract artist Ernst Wilhelm Nay (1902-1968) or the informal artist Hans Hartung (1904-1989). Haftmann was reluctant to institutional work positions within the art system and, throughout his life, praised the benefits of being a freelance writer ${ }^{24}$. Nevertheless, when he accepted the position of the director of the Neue Nationalgalerie, he affirmed that this post represented to him the chance to finally put in practice his theoretical work ${ }^{25}$. His curatorial activity at the Neue Nationalgalerie finalized the work started on Documenta exhibitions in Kassel shaping a permanent modern art collection in a long-lasting museum.

During his mandate, Haftmann's curatorial concept at the Neue Nationalgalerie was both praised for the quality of exhibitions and acquisitions, and blamed for its conservatism and lack of courage. In her article titled From the Accumulation to the World Gallery. Berlin Nationalgalerie's Acquisition Policy: Single Pieces and Little Contemporary published on August 14, 1970 in the Frankfurter Allgemeine Zeitung the editor, Camilla Blechen, criticized, among other things, Haftmann's exhibitions program. She wrote that the list of names contained in a pamphlet about the 1971 and 1972 contemporary art exhibitions program including, for instance, the cubist French-American sculptor Jacques Lipchitz (1891-1973) (Fig. 4), the Swiss

24 See for instance the correspondence with Erhard Göpel, File: Haftmann, Werner, Göpel, Ana 415, Bayerische Staatsbibliothek, Abteilung Handschriften, Munich, and the correspondence with Hans Purrmann, Hans Purrmann Archiv, Munich.

25 H. K. Der neue Direktor stellt sich vor. Pressekonferenz mit Dr. Werner Haftmann. Berliner Morgenpost. 25 February 1967. Presse-AdK-W 062, Presse-Archiv, Historisches Archiv Akademie der Künste, Berlin. 
painter Otto Meyer-Amden (1885-1933), and the Norwegian painter Edvard Munch (18631944) was "symptomatic of the delay at the Neue Nationalgalerie"26.

Haftmann resigned from his position ahead of schedule in 1974, officially for health reasons, and moved back to Italy establishing himself in San Casciano, near Florence, the city where his professional career began. During his farewell speech, Haftmann acknowledged to be "halfway satisfied [with his achievements at the museum] but also very exhausted." He deplored the lack of communication with galleries and art institutions in West Berlin, the difficulties related to the inadequacy of public funding for the museum, as well as the fact that the local realist artists were facilitated on the city art scene ${ }^{27}$. Analysing the German press, it is worth noting that the interpretation of Haftmann's retirement was read as a consequence of his disappointment about his curatorial experience at the Neue Nationalgalerie ${ }^{28}$. In this regard, the attention should be paid to the similarity with the circumstances that brought Haftmann to leave the Documenta curatorial board in Kassel apparently related to misunderstandings about the exhibition concept which arose in 1964, during the third edition titled International Exhibition. Haftmann's concept of the show based, once again, on the modern art masters of the beginning of the $20^{\text {th }}$ century, as well as his theory stating that "art is what the great artists do" were vigorously criticized. Arnold Bode pushed for a shift in contemporary art, but Haftmann didn't agree with that [34, pp. 8-10].

Once retired from the museum job, Haftmann dedicated himself exclusively to the historical research and publications on modern artists. The appointment of Dieter Honisch (19322004) as his successor at the Neue Nationalgalerie who during his long mandate from 1975 until 1997 included in his curatorial program the diverse art movements neglected by Haftmann, such as the Nouveau réalisme or Zero group, marked a clear inflexion point for the museum [33, p. 32]. Honisch removed Mies van der Rohe's display system considered outdated and cumbersome and, besides exhibiting traditional paintings and sculptures, opened the Nationalgalerie to performances and site-specific installations [1, p. 7].

\section{References}

1. Bischoff U.; Grisebach L. 10 Jahre im neuen Haus. Berlin, Staatl. Museen Preuss. Kulturbesitz Publ., 1979. 86 p. (in German).

2. Bode A. Documenta: Kunst des 20. Jahrhunderts. Internationale Ausstellung im Museum Fridericianum, Catalogue. Munich, Prestel Publ., 1955. 63 p. (in German).

3. Bode A. II. Documenta '59: Kunst nach 1945. Malerei, Skulptur, Druckgraphik. Catalogue. Cologne, DuMont Schauberg Publ., 1959. 71 p. (in German).

4. Carnduff Ritchie A. (ed.). German Art of the 20 th Century. New York, Simon and Schuster Publ., 1957.239 p.

5. Dube W.-D. Vorwort. Lepik A.; Sattler C.; Dube W.-D. (eds.). Dreißig Jahre Neue Nationalgalerie. Berlin, Kahlfeldt Publ., 1998, pp. 3-6 (in German).

6. Fleischmann G. Nationalgalerie Staatliche Museen Preußischer Kulturbesitz. Verzeichnis der vereinigten Kunstsammlungen Nationalgalerie (Preußische Kulturbesitz) und Galerie des 20. Jahrhunderts (Land Berlin). Berlin, Mann Publ., 1968. 384 p. (in German).

26 Presse-AdK-W 062, Presse-Archiv, Historisches Archiv Akademie der Künste, Berlin.

27 P. H. G. Ein Leben für die Kunst gestritten. Berliner Morgenpost. 29 April 1982. Presse-AdK-W 062, Presse-Archiv, Historisches Archiv Akademie der Künste, Berlin.

28 Kuhn N. Herold der Moderne. Zum Tod des Kunsthistorikers Werner Haftmann. Der Tagesspiegel. 31 July 1999. Presse-AdK-W 062, Presse-Archiv, Historisches Archiv Akademie der Künste, Berlin. 
7. Förster K. Malerei, Skulptur: Documenta III. Internationale Ausstellung, Catalogue. Cologne, DuMont Schauberg Publ., 1964. 416 p. (in German).

8. Fox S. Cullinan Hall. A Window on Modern Houston. Journal of Architectural Education, 2001, vol. 54, no. 3, pp. $158-166$.

9. Grasskamp W. Becoming Global: From Eurocentrism to North Atlantic Feedback-documenta as an International Exhibition (1955-1972). On Curating. The Documenta Issue, 2017, vol. 33, pp. 97-108.

10. Haftmann W. Form und Wirklichkeit. Exkurs über deren Einheit in der modernen Kunst. Kunst der Nation, 1934, no. 15, p. 1 (in German).

11. Haftmann W. Grundsätzliches über neue Bildhauerei. Kunst der Nation, 1934, no. 17, p. 2 (in German).

12. Haftmann W. Der Maler Hans Jaenisch. Kunst der Nation, 1934, no. 18, p. 6 (in German).

13. Haftmann W. Zur Vielfältigkeit deutscher Kunst. Kunst der Nation, 1934, no. 24, p. 1 (in German).

14. Haftmann W. Hermann Teuber. Kunst der Nation, 1935, no. 3, p. 2 (in German).

15. Haftmann W. Paul Klee. Wege bildnerischen Denkens, 1961, Munich, Prestel Publ., 175 p. (in German).

16. Haftmann W. Das italienische Säulenmonument: Versuch zur Geschichte einer antiken Form des Denkmals und Kultmonuments und ihrer Wirksamkeit für die Antikenvorstellung des Mittelalters und für die Ausbildung des öffentlichen Denkmals in der Frührenaissance. Leipzig, Teubner Publ., 1939. 166 p. (in German).

17. Haftmann W. Piet Mondrian, Catalogue. Recklinghausen, Bongers Publ., 1968. 76 p. (in German).

18. Haftmann W. E. W. Nay (1902-1968), Catalogue. Cologne, Müller Publ., 1969. 39 p. (in German).

19. Haftmann W. Jacques Lipchitz: Skulpturen und Zeichnungen (1911-1968), Catalogue. Berlin, Neuer Berliner Kunstverein Publ., 1970. 115 p. (in German).

20. Haftmann W. Nationalgalerie 1967-1974. Ein Rückblick. Jahrbuch Preußischer Kulturbesitz, 1976, vol. 12, pp. 33-53 (in German).

21. Haftmann W. Der Mensch und seine Bilder. Aufsätze und Reden zur Kunst des 20. Jahrhunderts. Cologne, DuMont Publ., 1980. 344 p. (in German).

22. Haftmann W. Verfemte Kunst: bildende Künstler der inneren und äußeren Emigration in der Zeit des Nationalsozialismus. Cologne, DuMont Publ., 1986, 420 p. (in German).

23. Haftmann W. Malerei im 20. Jahrhundert 1. Eine Entwicklungsgeschichte mit über 500 Künstlerbiographien. Munich, Prestel Publ., 1987 (1954). 690 p. (in German).

24. Haftmann W. Malerei im 20. Jahrhundert 2. Eine Bildenzyklopädie mit 1011 Abbildungen. Munich, Prestel Publ., 1987 (1955). 539 p. (in German).

25. Haftmann W. Von den Inhalten der modernen Kunst (1959). Rede anlässlich der Eröffnung der "II. documenta" am 11.05.1959. Haftmann E.; Wirth W. (eds.). Das antwortende Gegenbild. Ausgewählte Texte 1947-1990. Munich, Hirmer Publ., 2012, pp. 41-58 (in German).

26. Haftmann W. Museum und Avantgarde (1969). Aus dem Festvortrag zur Jahrhundertfeier der Hamburger Kunsthalle. Haftmann E.; Wirth W. (eds.). Das antwortende Gegenbild. Ausgewählte Texte 1947-1990. Munich, Hirmer Publ., 2012, pp. 69-79 (in German).

27. Hardebusch C. Kulturforum. Wachter G. (ed.). Mies van der Rohes Neue Nationalgalerie in Berlin. Berlin, Vice-Versa-Verlag Publ., 1995, pp. 33-55 (in German).

28. Hildebrand S. Entwurf und Bau der Neuen Nationalgalerie. Wachter G. (ed.). Mies van der Rohes Neue Nationalgalerie in Berlin. Berlin; Kreuzberg, Vice-Versa-Verlag Publ., 1995, pp. 7-32 (in German).

29. Honisch D. Die Nationalgalerie Berlin. Recklinghausen, Bongers Publ., 1979. 386 p. (in German).

30. Lauterbach I. Der Central Collecting Point in München: Kunstschutz, Restitution, Neubeginn. Berlin; Munich, Deutscher Kunstverlag Publ., 2015. 256 p. (in German).

31. Lohan D. Skizzen der Erinnerung. Dreißig Jahre Neue Nationalgalerie. Lepik A.; Sattler C.; Dube W.-D. (eds.). Berlin, Kahlfeldt Publ., 1998, pp. 7-12 (in German).

32. Schneider A. Hans Hartung: Retrospektive 1921-1973. Gemälde, Tuschen und Zeichnungen: Catalogue. Berlin, Neuer Berliner Kunstverein, Nationalgalerie Publ., 1975. 51 p. (in German).

33. Schuster P.-K. Die Neue Nationalgalerie. Berlin, DuMont Publ., 2003. 228 p. (in German).

34. Schwarze D. Die Karriere einer Ausstellung: 60 Jahre documenta. Blickpunkt Hessen, 2015, vol. 19, p. 36 (in German).

35. Spagnolo-Stiff A. L'Istituto Germanico di Storia dell'Arte di Firenze tra le due dittature. Il caso del saggio di Werner Haftmann per la visita del Führer nel 1938. Il ritorno all'ordine 1938. L'immagine di Firenze per la visita del Führer. La primavera violentata, Catalogue. Florence, I quaderni dell'Archivio della CittàPubl., 2012, no. 4, pp. 77-87 (in Italian). 
36. Sweeney J. J. Le Cullinan Hall de Mies van der Rohe à Houston. L'Eil, Numéro spécial L’architecture au XXe siècle, 1963, no. 99, pp. 38-43 (in French).

37. Vandenberg M. Architecture in Detail, New National Gallery Berlin, Ludwig Mies van der Rohe. London, Phaidon Publ., 1998. 60 p.

38. Voigt W. In der Nachfolge von Sezession und Bauhaus. Wiederaufbau und Erhebung zur Hochschule für bildende Künste. Hartmut F. (ed.). Nordlicht. 222 Jahre. Die Hamburger Hochschule für bildende Künste am Lerchenfeld und ihre Vorgeschichte. Hamburg, Junius-Verlag Publ., 1999, pp. 326-368 (in German).

Title. Werner Haftmann as the Director of the Neue Nationalgalerie in Berlin (1967-1974): Survey of the Curatorial Concept in the West German National Modern Art Gallery during the Cold War

Author. Vincenza Benedettino - Ph. D. student. Heidelberg University, Seminarstraße 4, 69117 Heidelberg, Germany; École du Louvre, Palais du Louvre, Porte Jaujard, Place du Carrousel, 75038 Paris cedex 01, France. vincenza.benedettino@gmail.com

Abstract. This paper presents an overview of Werner Haftmann's curatorial activity as the director of the Neue Nationalgalerie in Berlin from 1967 until 1974. Before being appointed the director of the Neue Nationalgalerie in 1967, Haftmann curated the first three Documenta exhibitions in Kassel $(1955,1959$ and 1964). Since 1946, Haftmann's books and articles on German and international modern art were considered to have a pioneering role in rediscovering the work of many avant-garde artists who were banned by the National Socialist regime. By analysing Haftmann's curatorial concept at one of West Germany's most important national museums during the Cold War, this paper discusses some ideological and political aspects of his work. The research was undertaken in several public archives in Germany and abroad, in order to outline Haftmann's art historical and cultural horizon as the director of the Neue Nationalgalerie. The museum's architecture, built by Ludwig Mies van der Rohe from 1965 until 1968, had a considerable impact on Haftmann's purchase policy as well as on the organization of temporary exhibitions. Moreover, the hanging walls designed by the architect for the museum's ground floor hall challenged Haftmann's curatorial work and suggested a new way of perceiving the artworks on display. Haftmann, at the same time satisfied of his accomplishments and frustrated by the difficulties related to the museum director's job, resigned from his post in 1974 for health reasons and turned to the historical research and publication of books. The appointment of Dieter Honisch as his successor marked a clear change for the museum, both in terms of acquisitions and temporary exhibitions.

Keywords: Werner Haftmann, Neue Nationalgalerie, Ludwig Mies van der Rohe, West Berlin, Cold War, modern art collections, temporary exhibitions, acquisition policy, museology, exhibition display

\author{
Archives \\ Archiv der Akademie der bildenden Künste München. \\ Archiv der Neuen Pinakothek, Munich. \\ Archiv des Instituts für Kunstgeschichte der Universität Wien. \\ Bayerischer Rundfunk, Historisches Archiv, Munich. \\ Bayerische Staatsbibliothek, Abteilung Handschriften, Munich. \\ Bundesarchiv, Berlin. \\ Bundesarchiv, Abteilung Militärarchiv, Freiburg im Breisgau. \\ Hans Purrmann Archiv, Munich. \\ Historisches Archiv Akademie der Künste, Berlin. \\ Landesarchiv NRW, Abteilung Rheinland, Duisburg. \\ Staatliche Museen zu Berlin Preußischer Kulturbesitz, Zentralarchiv. \\ Stadtarchiv Kalkar. \\ Stadtarchiv Landeshauptstadt Magdeburg. \\ SUB Niedersächsische Staats- und Universitätsbibliothek Göttingen. \\ Universitätsarchiv der Humboldt-Universität, Berlin.
}

Название статьи. Вернер Хафтманн - директор Новой национальной галереи в Берлине (19671974). Исследование кураторских концепций в национальной галерее современного искусства Западной Германии в эпоху холодной войны

Сведения об авторе. Бенедеттино Винченца - аспирант. Гейдельбергский университет. Земинарштрассе 4, 69117 Гейдельберг, Германия; Школа Лувра. Лувр, Порте Жожар, пляс де Каррузель, 75038 Париж, Седекс 01, Франция. vincenza.benedettino@gmail.com 
Аннотация. Статья представляет обзор кураторской деятельности Вернера Хафтманна на посту директора Новой национальной галереи в Берлине в период с 1967 по 1974 г. До назначения на этот пост Хафтманн был куратором первых трёх выставок Documenta в Касселе $(1955,1959,1964)$. С 1946 г. книги и статьи Хафтманна о немецком и международном искусстве модернизма играли ключевую роль в новом открытии многих художников авангарда, которые оказались под запретом при национал-социалистах. На основании изучения кураторских концепций Хафтманна в одном из важнейших национальных музеев Западной Германии эпохи холодной войны автор выделяет ряд идеологических и политических аспектов его работы. Чтобы более рельефно показать фигуру Хафтманна как историка искусства, деятеля культуры и директора Новой национальной галереи, был проведён сбор материалов в нескольких публичных архивах в Германии и за рубежом. Архитектура музея, построенного Людвигом Мисом ван дер Роэ в 1965-1968 гг., оказала значительное влияние на политику закупок Хафтманна и на организацию временных выставок. Более того, подвесные стены, спроектированные архитектором для залов первого этажа музея, усложнили кураторскую работу Хафтманна и подтолкнули его к новым способам восприятия экспонатов. Хафтманн, удовлетворённый своими достижениями и в то же время столкнувшийся с трудностями на посту директора музея, ушёл в отставку в 1974 г. по состоянию здоровья и решил полностью посвятить себя исследованиям и написанию книг по истории искусства. Назначение Дитера Хониша в качестве преемника Хафтманна ознаменовало перемены как в политике закупок музея, так и в стратегии временных выставок.

Ключевые слова: Вернер Хафтманн, Новая национальная галерея, Людвиг Мис ван дер Роэ, Западный Берлин, холодная война, коллекции современного искусства, временные выставки, политика пополнения коллекций, музеология, экспозиция 